\title{
An integrated approach to analyze strategy map using BSC - FUZZY AHP: A case study of auto industry
}

\author{
Mohammad Abdolshah $^{\mathrm{a}}$, Mojtaba Javidnia ${ }^{\mathrm{b}^{*}}$, Mohammad Ali Astanbous ${ }^{\mathrm{b}}$, and Mehdi Eslami ${ }^{\mathrm{c}}$
}

${ }^{a}$ Department of Management, Islamic Azad University, Semnan Branch, Semnan, Iran

${ }^{b}$ Department of Management, Young Researchers Club, Islamic Azad University, Semnan Branch, Semnan, Iran ${ }^{c} \mathrm{MSc}$ in Materials Engineering

\begin{tabular}{l}
\hline A R T I C L E I N F O \\
\hline Article history: \\
Received July 10, 2011 \\
Received in Revised form \\
October, 3, 2011 \\
Accepted 15 January 2012 \\
Available online \\
19 January 2012 \\
\hline Keywords: \\
Strategy map \\
BSC \\
FAHP
\end{tabular}

\section{Introduction}

In today's highly competitive global environment, companies strongly consider the efficiency and performance associated with their all sources to achieve long-term competitive advantages. To protect competitive advantages, organizations must constantly monitor their performance measurement systems for operational measurement using assessment model to help them plan future strategies and set up performance targets of employees to achieve the final target of the entire organizations (Wu et al., 2011). The effective measurement systems, as a useful tool, enable many managers to control and monitor companies to process and to improve to achieve higher productivity and performance. An expanding model for measurement of companies operations is balanced score card (BSC), which is based on interaction financial, customer, internal process, learning and growth (Wang et al., 2010). 
The implementation of BSC is fairly straightforward by expanding strategy goals of organization and performance indicators. There are different advantages of using BSC: (A) it provides a balance between long terms strategies and short terms actions, it provides link between long term and short terms goals, it provides relationship between financial and non financial indicators and finally it create relationship between each four strategic aspects (Xu \& Yeh, 2012). During the past two decades, BSC has been widely used in companies and different private and public organizations. BSC has been able to establish comprehensive system management approaches at the head of the organization (Creelman \& Makhijani., 2005; Niven, 2008). BSC has also been used as a frame for criteria categorization and measurement indicators, for evaluating solution set in deferent parts such as investment, research projects, ERP systems and banks (Xu \& Yeh, 2012).

In this paper, we use BSC to categorize strategic goals in strategy map of a case study of auto makers in Iran called Electric Vehicle Co. East and operational indicators, which are associated with these goals .

\section{Balanced score card}

Kaplan and Norton (1996, 2000) explained the need for effective fulfillment of strategies and creating the comprehensive system of management and improving the performance by introducing BSC. Management system of balanced scorecard has been proposed as an expanding and comprehensive frame for evaluating operation and developing strategy, which leads to create a balance between short terms and long terms goals, financial and non-financial indicators, inside and outside operation and conductor indicators and performance function. BSC is a proven framework, which operates organization strategy (Niven, 2006; Creelman \& Makhijani, 2008). Fig. 1 shows details of the implementation of BSC method. BSC enables expression of the vision and strategies of a business in terms of performance indicators and thus ensures establishment of the framework required for strategic measurement and management system. While underlying that traditional financial indicators are important, BSC describes that financial indicators are proven to be insufficient in explaining the business performance since they only contain the information associated with the issues taken place in the past and we cannot rely on these factors (Yuksel \& Dagdeviren, 2010). Kaplan and Norton explained four perspectives needed to create a balance in measurement of organization performance in terms of financial, customer, internal process, learning and growth.

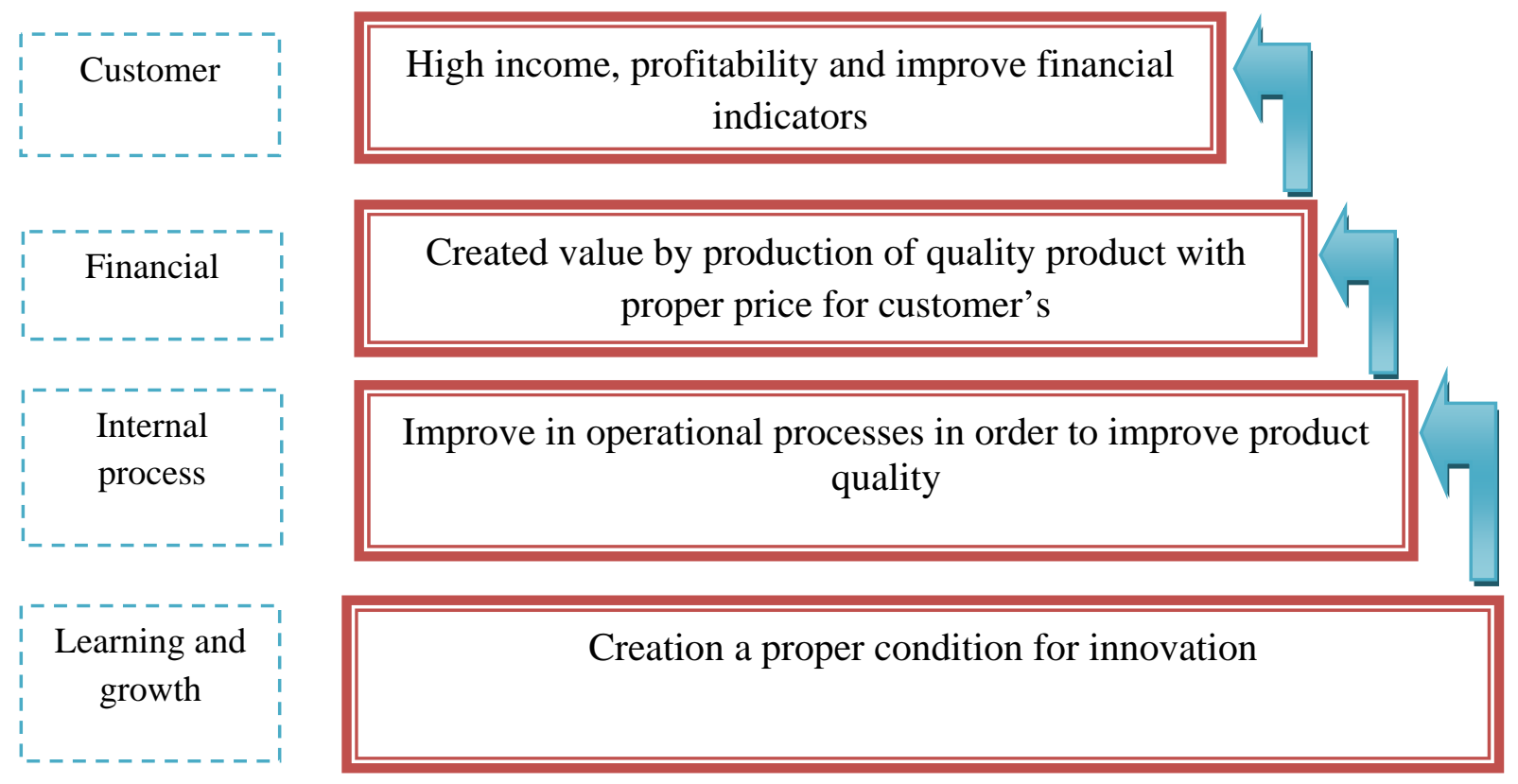

Fig.1. Relations between different aspects of BSC 
By considering these four views, financial factors are considered along with other important factors. However, BSC has some limitations (Abran \& Buglione, 2003; Lee et al., 2008 Leung et al., 2006). Kaplan and Norton argued that the BSC program involves a cause-and-effect relationship among different factors in selected perspectives. Similarly, numerous different scholars have provided empirical evidence supporting the existence of a cause-and-effect relationship among BSC various perspectives (Schmidberger, et al., 2009).The relationship reflects the interplay and interdependencies among financial and non-financial measures. A well-constructed BSC method must consider the interactive relationship among various selected perspectives and their measurement criteria (Wang et al., 2010; Lee et al., 2008). There are literally many studies on BSC but there is a little attention on how to implement this model in uncertain situations (Tseng, 2010). Table 1 shows some of the important issues.

\section{Table 1}

Previous studies in BSC

\begin{tabular}{|c|c|c|}
\hline Title & Author/ year & Description \\
\hline $\begin{array}{l}\text { Strategic performance measurement in a } \\
\text { healthcare organization : A multiple } \\
\text { criteria approach based on balanced score }\end{array}$ & $\begin{array}{l}\text { Grigoroudis et } \\
\text { al., } 2012\end{array}$ & $\begin{array}{l}\text { The main purpose of this study is representing a performance measurement } \\
\text { system for health care organizations. The work measures indicators including } \\
\text { both financial and non-financial indicators and the results indicated that } \\
\text { learning and growth aspect in these organizations is most important than other } \\
\text { aspects. }\end{array}$ \\
\hline $\begin{array}{l}\text { An integrated approach to evaluation } \\
\text { and planning of best practices }\end{array}$ & $\begin{array}{l}\text { Xu and Yeh, } \\
2012\end{array}$ & $\begin{array}{l}\text { In this paper, using a multifaceted decision-making algorithm based on the } \\
\text { BSC, a new evaluation model was driven for affective measurement of } \\
\text { relationship between low-level and high-level goals in organizations. }\end{array}$ \\
\hline $\begin{array}{l}\text { Extracting leanness criteria by employing } \\
\text { the concept of Balanced Scorecard }\end{array}$ & $\begin{array}{l}\text { Seyedhosseini et } \\
\text { al., } 2011\end{array}$ & $\begin{array}{l}\text { The work uses BSC concept to derive indices of low efficiency and to } \\
\text { achieving this purpose, set of company's goals based on different aspects of } \\
\text { BSC was extracted from the company's strategic map and their performances } \\
\text { were evaluated. }\end{array}$ \\
\hline $\begin{array}{l}\text { Performance evaluation of extension } \\
\text { education centers in universities based on } \\
\text { the balanced scorecard }\end{array}$ & Wu et al., 2011 & $\begin{array}{l}\text { In this paper, } 36 \text { indicator in } 4 \text { aspect of BSC was evaluated in educational } \\
\text { centers of Taiwan and by use of DEMATEL, ANP, VICOR. }\end{array}$ \\
\hline $\begin{array}{l}\text { Developing strategic measurement and } \\
\text { improvement for the biopharmaceutical } \\
\text { firm: Using the BSC hierarchy }\end{array}$ & $\begin{array}{l}\text { Huang et al., } \\
2011\end{array}$ & $\begin{array}{l}\text { In this study, BSC is used to evaluate the performance biopharmaceutical firm } \\
\text { and it was used from combination AHP with BSC techniques. }\end{array}$ \\
\hline $\begin{array}{l}\text { Implementation and performance } \\
\text { evaluation using the fuzzy network } \\
\text { balanced scorecard }\end{array}$ & Tseng, 2010 & $\begin{array}{l}\text { Tang used BSC in Taiwan universities in order to evaluate multiple criteria } \\
\text { associated with BSC using DEMATEL method. }\end{array}$ \\
\hline $\begin{array}{l}\text { Integrating hierarchical balanced } \\
\text { scorecard with non-additive fuzzy } \\
\text { integral for evaluating high technology } \\
\text { firm performance }\end{array}$ & $\begin{array}{l}\text { Wang et al., } \\
2010\end{array}$ & $\begin{array}{l}\text { They showed that represented system of performance evaluation in this study } \\
\text { could be effective in eliminating some issues created goals by high level } \\
\text { manager and employees. }\end{array}$ \\
\hline $\begin{array}{l}\text { A Fuzzy DEMATEL framework for } \\
\text { modeling cause and effect relationships } \\
\text { of strategy map }\end{array}$ & $\begin{array}{l}\text { Jassbi et al., } \\
2010\end{array}$ & $\begin{array}{l}\text { In this study } 15 \text { available indicators of strategy map in an auto-maker } \\
\text { company was evaluated using BSC perspective. The study evaluated } \\
\text { competitors evaluate, capability of learning and fast service network, } \\
\text { comprehensive support system based on new technologies, up to date network } \\
\text { services to meet customers' needs and processes and educational policy and } \\
\text { learning of Human capital was identified as affecting indicators . }\end{array}$ \\
\hline $\begin{array}{l}\text { Analyzing BSC and IC's usefulness in } \\
\text { nonprofit organizations }\end{array}$ & Kong, 2010 & $\begin{array}{l}\text { In this study, the non-profit organizations to transfer knowledge from the } \\
\text { perspective of human capital, structural capital and relational capital was } \\
\text { investigated }\end{array}$ \\
\hline $\begin{array}{l}\text { Using the fuzzy analytic network process } \\
\text { (ANP) for Balanced Scorecard (BSC):A } \\
\text { case study for a manufacturing firm }\end{array}$ & $\begin{array}{l}\text { Yuksel and Dag } \\
\text { deviren, } 2010\end{array}$ & $\begin{array}{l}\text { In this study, BSC procedure with fuzzy ANP has been integrated to } \\
\text { determine the level of business performance based on company goals and } \\
\text { strategies. Result of this combination model shows that Combining these two } \\
\text { techniques can be fuller and more accurate the results achieved. }\end{array}$ \\
\hline $\begin{array}{l}\text { Designing a knowledge-based system for } \\
\text { strategic planning: A balanced scorecard } \\
\text { perspective }\end{array}$ & Huang, 2009 & $\begin{array}{l}\text { In this paper author used a combination of BSC and AHP methods for } \\
\text { performance evaluation of a knowledge-based systems in terms of four BSC } \\
\text { views. }\end{array}$ \\
\hline $\begin{array}{l}\text { Evaluating petroleum supply chain } \\
\text { performance: Application of analytical } \\
\text { hierarchy process to balanced scorecard }\end{array}$ & $\begin{array}{l}\text { Varma et al., } \\
2008\end{array}$ & $\begin{array}{l}\text { In this paper, a combination of AHP and BSC to evaluate performance of the } \\
\text { supply chain of crude oil was used. }\end{array}$ \\
\hline $\begin{array}{l}\text { evaluation of performance of society } \\
\text { assurance organization by used of } \\
\text { combination FDEA and BSC }\end{array}$ & $\begin{array}{l}\text { Momeni et al., } \\
2010\end{array}$ & $\begin{array}{l}\text { In this paper, first, operation level of branches was computed by balancing } \\
\text { scorecard and then efficiency of these branches are measured based on fuzzy } \\
\text { DEA. }\end{array}$ \\
\hline $\begin{array}{l}\text { evaluation of National Nanotechnology } \\
\text { Program with balancing scoredcard in } \\
\text { Iran }\end{array}$ & $\begin{array}{l}\text { Ghazi noori \& } \\
\text { Tavasolizadeh, } \\
2009\end{array}$ & $\begin{array}{l}\text { This study was designed to utilize strategy map and it provided a BSC about } \\
\text { technological strategy in national level. }\end{array}$ \\
\hline
\end{tabular}




\section{Strategy map}

The inventors of the BSC believe that successful strategy depends on understanding organization components, very carefully (Kaplan \& Norton, 2000). Drawing precise causal relationships among the organization's strategic goals in the four perspectives can be used as a foundation for BSC. The case study of this paper is called Electric Vehicle Co. East, which was established in 1974 and produced some of the vehicle components such as wire dart established.

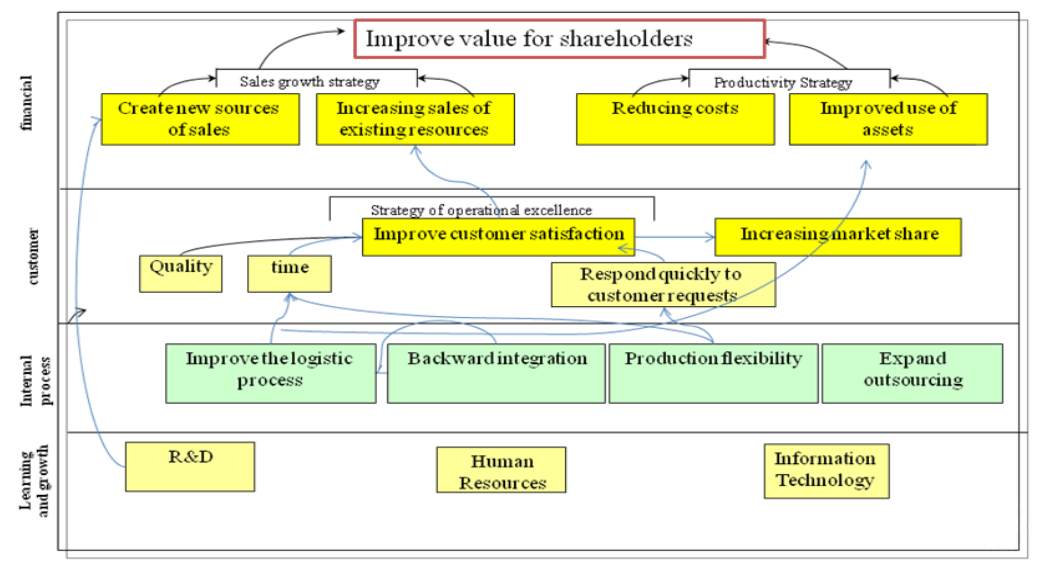

Fig. 2. Strategy map

The main activities of the company is production, export, import different kinds of wire dart and its components and engineering services, designing and manufacturing various automobile parts. Electric Vehicle Co. East has domestically considered as the best electrical and electronic automotive parts supplier in the country by using of new technology and it has succeeded to design, produce and supply parts for domestic and international arena. Some of the most important strategic goals are summarized in Fig. 3.

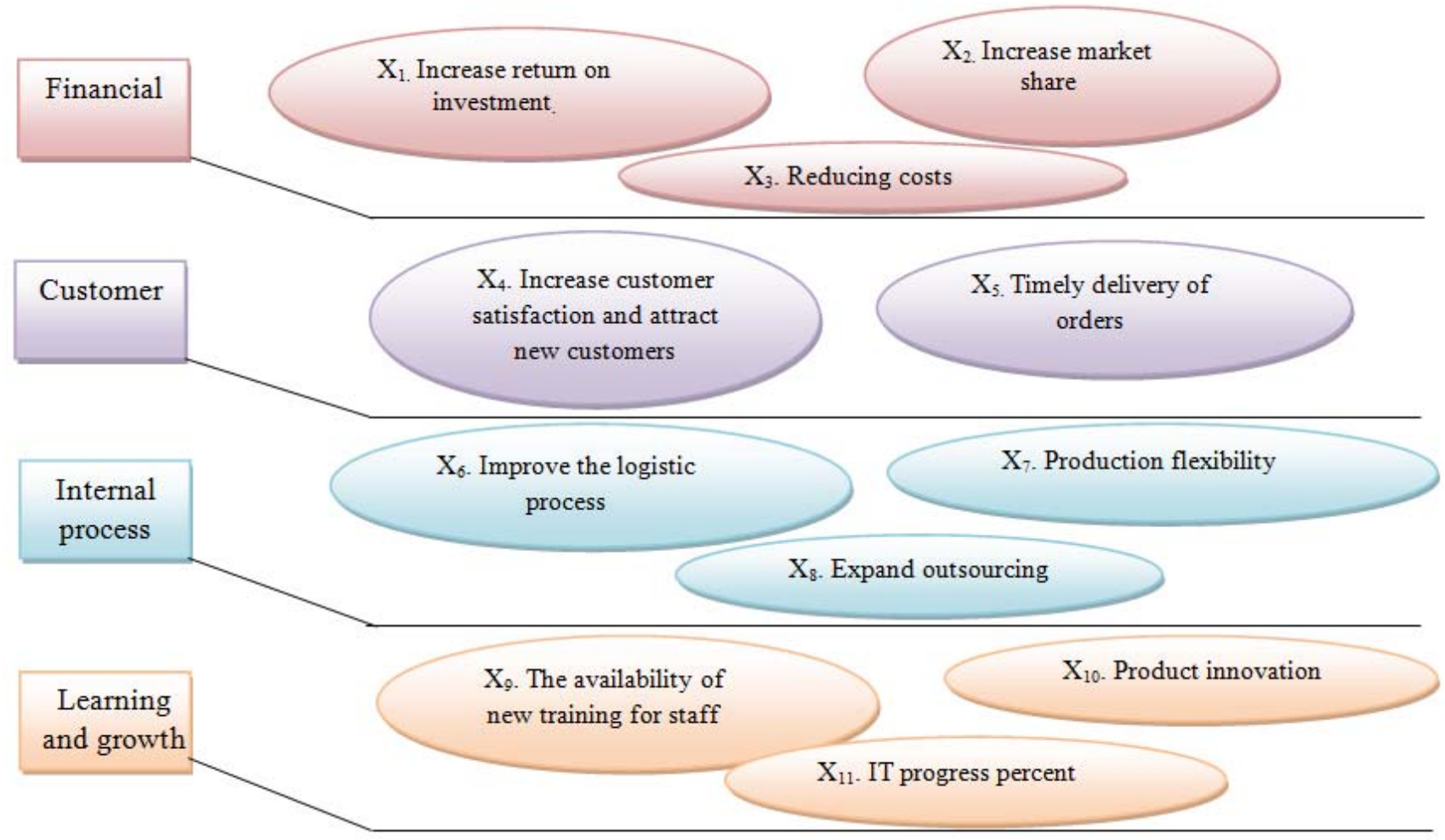

Fig.3. plan of strategy map of Electric Vehicle Co. East 


\section{Fuzzy analysis hierarchical process (FAHP)}

Process of fuzzy analysis hierarchy process which widely used in Multi Criteria Decision Making,was proposed by saaty in 1971 and In order to solve design requirements and the allocation of scarce military resources(Saaty, 1980). Since then, AHP has been one of the most extensive and most widely used multi-criteria decision making methods used in many applications. However, previously, this method was successful in many cases but beside of this and in real world, representation of accurate size of factors is very difficult and priority option has always been associated with uncertainty. To resolve this problem and to remove the possible ambiguities in some of the judgments, there have implementation of fuzzy methods to handle uncertainty (Heo et al., 2010).

In order to do this and for achieving proper result, in this paper, we use fuzzy analysis hierarchy process method (FAHP). Process of hierarchical BSC decision making, has been illustrated in Fig. 4.

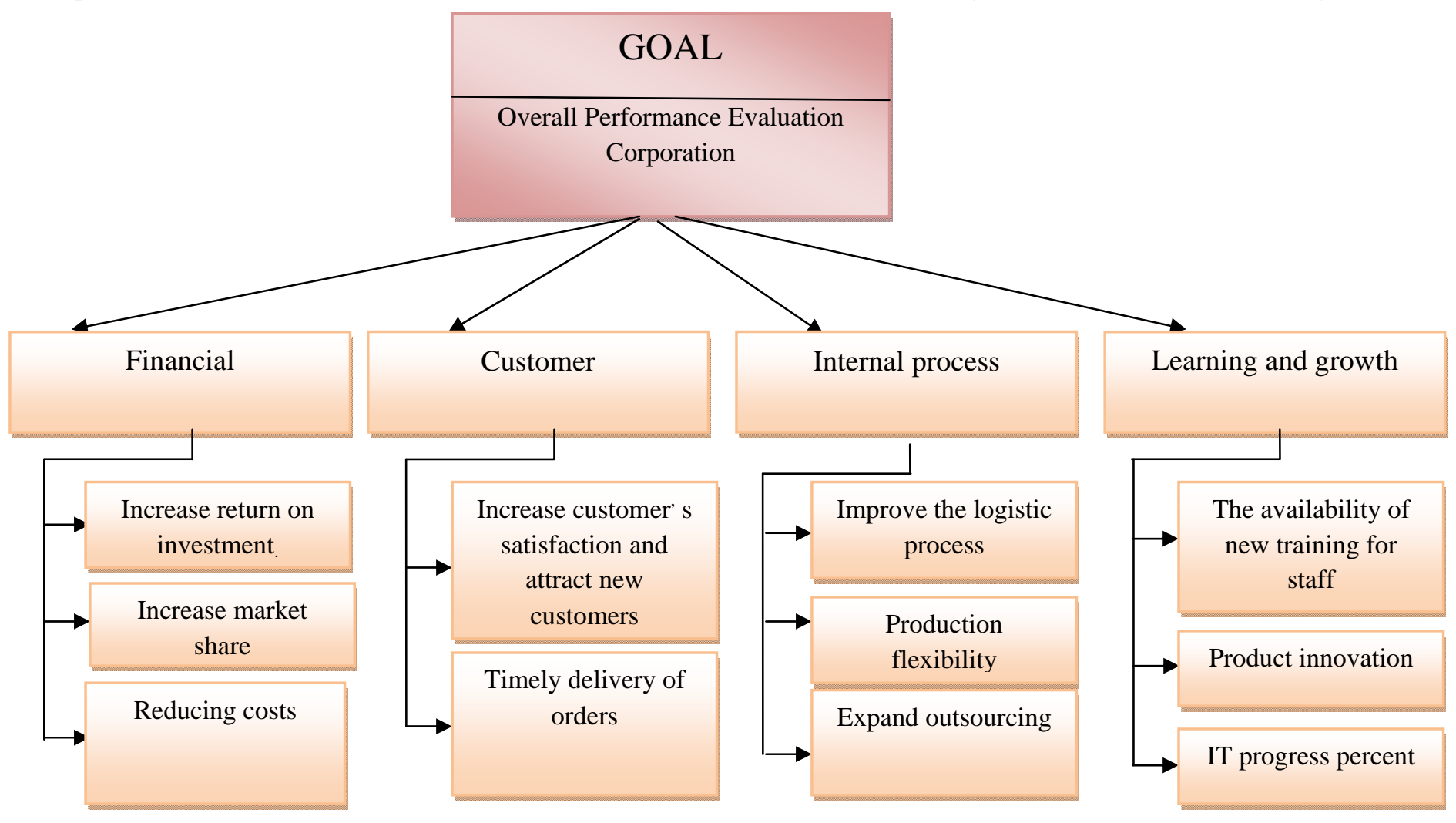

Fig. 4. process of hierarchical BSC decision making

There are many methods in terms of fuzzy analysis hierarchy process (FAHP) for handling uncertainties. These methods represent systematic procedure in item selection by use of theory of fuzzy setting and analysis hierarchical (Bozbura et al., 2007). The proposed model of this paper has originally been developed by Chang (1996) and it uses triangular numbers as shown in Table 2 .

\section{Table 2}

Linguistic terms for the fuzzy ratings

\begin{tabular}{|c|c|c|}
\hline Linguistic terms & Triangular fuzzy numbers & Reverse triangular fuzzy numbers \\
\hline Equal preference & $(1,1,3)$ & $(1 / 3,1,1)$ \\
\hline Rather weak & $(1,3,5)$ & $(1 / 5,1 / 3,1)$ \\
\hline Rather good & $(3,5,7)$ & $(1 / 7,1 / 5,1 / 3)$ \\
\hline Strong preference & $(5,7,9)$ & $(1 / 9,1 / 7,1 / 5)$ \\
\hline Absolute preference & $(7,9,9)$ & $(1 / 9,1 / 9,1 / 7)$ \\
\hline
\end{tabular}


The following summarizes the steps of FAHP method,

First step: For each row of a matrix of paired comparisons, $s_{k}$, which is a triangular number is calculated as follows,

$S_{k}=\sum_{j=1}^{n} M_{k j} \times\left[\sum_{i=1}^{m} \sum_{j=1}^{n} M_{i j}\right]^{-1}$

where $K$ represents row number and $i$ and $j$ are the options and the index and

$\sum_{j=1}^{n} M_{k j}=\left(\sum_{i=1}^{n} l_{i}, \sum_{i=1}^{n} m_{i}, \sum_{i=1}^{n} u_{i}\right),\left[\sum_{i=1}^{m} \sum_{j=1}^{n} M_{i j}\right]^{-1}=\left(\frac{1}{\sum_{i=1}^{n} u_{i}}, \frac{1}{\sum_{i=1}^{n} m_{i}}, \frac{1}{\sum_{i=1}^{n} l_{i}}\right)$

Second step: Let $M_{1}$ and $M_{2}$ be two triangular fuzzy numbers, large degree of $m_{2}$ on $m_{1}$ is calculated as fallow,

$V\left(M_{2} \geq M_{1}\right)=\left\{\begin{array}{ccc}1 & \text { if } & \mathrm{m}_{2} \geq m_{1} \\ 0 & \text { if } & l_{1} \geq u_{2} \\ \frac{l_{1}-u_{2}}{\left(m_{2}-u_{2}\right)-\left(m_{1}-l_{1}\right)} & & \text { otherwise }\end{array}\right.$

Third step: To compare two triangular number we use the following,

$V\left(\mathrm{M}_{1} \geq M_{2}, \ldots, \mathrm{M}_{\mathrm{k}}\right)=\min \left[V\left(\mathrm{M}_{1} \geq M_{2}\right), \ldots, V\left(\mathrm{M}_{1} \geq M_{\mathrm{k}}\right)\right]$

$d\left(A_{i}\right)=\min \left\{V\left(\mathrm{~S}_{\mathrm{i}} \geq S_{\mathrm{k}}\right)\right\}, k=1,2, \ldots, n \quad k \neq i$

Then, the weight vector is obtained and they are normalized as follows,

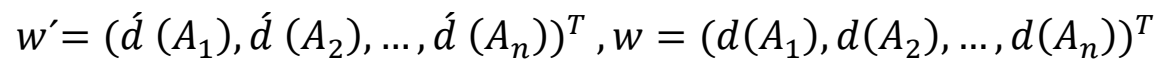

Table 3

Corresponding weights for each strategy and the corresponding weight of each aspect

\begin{tabular}{|c|c|c|}
\hline Aspects and strategies & $\begin{array}{l}\text { Weight corresponding to } \\
\text { each aspect (\%) }\end{array}$ & $\begin{array}{l}\text { Weight corresponding to } \\
\text { selection each strategy(\%) }\end{array}$ \\
\hline Financial & 38.7059 & \\
\hline $\mathrm{X}_{1}$. Increase return on investment. & & 14.5943 \\
\hline $\mathrm{X}_{2 .}$ Increase market share & & 13.7309 \\
\hline $\mathrm{X}_{3}$. Reducing costs & & 10.3807 \\
\hline Customer & 22.9432 & \\
\hline $\begin{array}{l}\mathrm{X}_{4} \text { Increase customer satisfaction and attract new } \\
\text { customers }\end{array}$ & & 12.5781 \\
\hline $\mathrm{X}_{5 .}$ Timely delivery of orders & & 10.3651 \\
\hline Internal process & 19.9588 & \\
\hline $\mathrm{X}_{6}$. Improve the logistic process & & 7.9980 \\
\hline $\mathrm{X}_{7}$. Production flexibility & & 7.5169 \\
\hline $\mathrm{X}_{8}$. Expand outsourcing & & 4.4439 \\
\hline Learning and growth & 18.3921 & \\
\hline $\mathrm{X}_{9}$. The availability of new training for staff & & 7.5679 \\
\hline $\mathrm{X}_{10}$. Product innovation & & 6.5001 \\
\hline $\mathrm{X}_{11}$. IT progress percent & & 4.3241 \\
\hline
\end{tabular}




\section{Table 4}

Penetration of each strategy in the perspective

\begin{tabular}{ll}
\hline Aspects and strategies & Penetration of each strategy in the aspect (\%) \\
\hline $\mathrm{X}_{1}$ Increase return on investment. & 37.7056 \\
$\mathrm{X}_{2 .}$ Increase market share & 35.4749 \\
$\mathrm{X}_{3}$. Reducing costs & 26.8194 \\
$\mathrm{X}_{4}$. Increase customer satisfaction and attract new customers & 54.8227 \\
$\mathrm{X}_{5}$ Timely delivery of orders & 45.1772 \\
$\mathrm{X}_{6}$. Improve the logistic process & 40.0725 \\
$\mathrm{X}_{7}$. Production flexibility & 37.6620 \\
$\mathrm{X}_{8}$. Expand outsourcing & 22.2653 \\
$\mathrm{X}_{9}$. The availability of new training for staff & 41.1475 \\
$\mathrm{X}_{10}$. Product innovation & 35.3418 \\
$\mathrm{X}_{11}$. IT progress percent & 23.5106 \\
\hline
\end{tabular}

\section{Conclusion}

The first step at assessing one organization function is to select the assessment model proportion with dimensions in which basis decision makers will measure their units. While each assessment method has its own special weakness and strength, combining different models for developing the assessment process can assist decision makers to examine organizations functions more accurately. In this article, we have used a hybrid method to evaluate the performance of firm from auto industry based on a combination of FAHP and BSC methods. The proposed study used 4 main aspects of BSC which including financial, customer, internal processes, learning and growth. We have also used fuzzy methods to handle uncertainty. The results showed that increase return on investment, in the view point of managers and share holders has the highest importance weight, and progress of IT percent has the lowest importance weight. The results showed that in terms of financial, customer, internal process, learning and growth, respectively, the indicators of increase return on investment, increase customer satisfaction, improvement the logistic process and availability of new and appropriate training for staff have the highest importance weights.

\section{References}

Abran, A., \& Buglione, L. (2003). A multidimensional performance model for consolidating balanced scorecards. Advances in Engineering Software, 34, 339-349.

Bozbura, F.T., Beskese, A. \& Kahraman, C. (2007). Prioritization of human capital measurement indicators using fuzzy AHP. Expert Systems with Applications, 32, 1100-1112.

Chang, D.Y. (1996). Applications of the extent analysis method on fuzzy AHP. European Journal of Operational Research, 649-655.

Chytas, P. (2008). A proactive fuzzy cognitive balanced scorecard, IEEE World Congress on Computational Intelligence Systems.

Creelman, J., \& Makhijani, N. (2005). Succeeding with the balanced scorecard in the mastering business in Asia series, Wiley Executive.

Creelman, J., \& Makhijani, N. (2008). How leading organizations successfully implement corporate strategy with the balanced scorecard. The OTI Thought Leadership Series, 1, 1-16.

Ghazi noori, S., \& Tavasolizadeh, S. (2009). evaluation of National Nanotechnology Program with balancing scorecard in Iran. Journal of science \& technology, 4.

Grigoroudis, E., Orfanoudaki, E., \& Zopounidis, C. (2012). Strategic performance measurement in a healthcare organization : Amultiple criteria approach based on balanced score. Omega, 40, 104119.

Heo, E., Kim, J., \& Boo, K.J. (2010). Analysis of the assessment factors for renewable energy dissemination program evaluation using fuzzy AHP. Renewable and Sustainable Energy Reviews. 
Huang, H. C. (2009). Designing a knowledge-based system for strategic planning: A balanced scorecard perspective. Expert Systems with Applications, 36(1), 209-218.

Huang, H.C., Lai, M.C., Lin, L.H. (2011). Developing strategic measurement and improvement for the biopharmaceutical firm: Using the BSC hierarchy. Expert Systems with Applications, 38, 4875-4881

Jassbi, J., Mohamadnejad, F., \& Nasrollahzadeh, H. (2011). A Fuzzy DEMATEL framework for modeling cause and effect relationships of strategy map. Expert Systems with Applications, 38, 5967-5973.

Kaplan, R. S., \& Norton, D. P. (1996b). The balanced scorecard: translating strategy into action. Boston: Harvard Business School Press.

Kaplan, R. \& Norton, D. (2000). The strategy-focused organization: How balanced scorecard companies thrive in the new business environment. Harvard Business School Press.

Kong , E. (2010). Analyzing BSC and IC's usefulness in nonprofit organizations. Journal of Intellectual Capital, 11(3), 284-304.

Lee, A. H. I., Chen, W. C., \& Chang, C. J. (2008). A fuzzy AHP and BSC approach for evaluating performance of IT department in the manufacturing industry in Taiwan. Expert Systems with Applications, 34, 96-107.

Leung, L. C., Lam, K. C., \& Cao, D. (2006). Implementing the balanced scorecard using the analytic hierarchy process and the analytic network process. Journal of the Operational Research Society, 57, 682-691.

Momeni, M., Khodaei, S., \& Bashiri, M. (2010). Evaluation of performance of society assurance organization by used of combination FDEA and BSC. Journal of industrial management, 3, 137152.

Niven P. R. (2008). Balanced scorecard : Step-by-step for government and nonprofit agencies, Wiley, $2^{\text {nd }}$ ed.

Niven P., R. (2006). Balanced scorecard step-by-step: Maximizing performance and maintaining results, 2 Edition, John Wiley \& Sons, 2006.

Saaty, T. L. (1980). The Analytic Hierarchy Process. New York: McGraw-Hill.

Schmidberger, S., Bals, L., Hartmann, E., \& Jahns, C. (2009). Ground handling services at European hub airports: development of a performance measurement system for benchmarking. International Journal of Production Economics, 117, 104-111.

Seyedhosseini, S.M., Taleghani, A.E., Bakhsha, A. and Partovi, S. (2011). Extracting leanness criteria by employing the concept of Balanced Scorecard,Journal of Expert Systems with Applications 38 .pp. 10454-10461.

Tseng, M.L. (2010). Implementation and performance evaluation using the fuzzy network balanced scorecard. Journal of Computers \& Education, 55, 188 -201.

Varma, S., Wadhwa, S., \& Deshmukh, S. G. (2008). Evaluating petroleum supply chain performance: Application of analytical hierarchy process to balanced scorecard. Asia Pacific Journal of Marketing and Logistics, 20(3), 343-356.

Wang, C.H., Lu, I.Y., \& Chen, C.B. (2010). Integrating hierarchical balanced scorecard with nonadditive fuzzy integral for evaluating high technology firm performance. International Journal of Production Economics, 128, 413-426.

Wu, H.Y., Lin, Y.K., \& Chang, C.H. (2011). Performance evaluation of extension education centers in universities based on the balanced scorecard. Journal of Evaluation and Program Planning, 34, 37-50.

Xu , Y., \& Yeh, C.H. (2012). An integrated approach to evaluation and planning of best practices. Omega, 40, 65-78.

Yuksel, I., \& Dag deviren, M. (2010). Using the fuzzy analytic network process (ANP) for Balanced Scorecard (BSC): A case study for a manufacturing firm. Expert Systems with Applications, 37, 1270-1278. 